\title{
Expression of nodD1 and nodD2 in Sinorhizobium fredii, a Nitrogen-Fixing Symbiont of Soybean and Other Legumes
}

\author{
Daphne Machado, ${ }^{1}$ Steven G. Pueppke, ${ }^{1}$ José Maria Vinardel, ${ }^{2}$ José E. Ruiz-Sainz, ${ }^{2}$ and \\ Hari B. Krishnan 1 \\ ${ }^{1}$ Department of Plant Pathology, University of Missouri, Columbia 65211, U.S.A.; ${ }^{2}$ Departamento de \\ Microbiología, Faculdad de Biología, Universidad de Sevilla, Apdo. 1095, 41080-Sevilla, Spain \\ Accepted on 13 January 1998.
}

\begin{abstract}
The ability of Sinorhizobium fredii strains USDA191 and USDA257 to form nitrogen-fixing root nodules on legume plants is regulated by nodD1 and nodD2, which sense flavonoid signals from host roots and then activate the expression of inducible nodulation genes. We assessed the interactions between these two loci with nodD1-negative and nodD2-negative mutants and with strains containing extra copies of these genes. Although both nodD1 and nodD2 are expressed constitutively, levels of nodD1 are much higher, as measured by RNA dot blots. Extra plasmid-borne copies of nodD2 reduced transcription of nodD1 to below the level of detection. We employed gel mobility shift assays to demonstrate that cellular proteins from flavonoid-treated cultures of strain USDA191 bind to DNA sequences that lie upstream from nodD1, but not to the corresponding region upstream from nodD2. Extra plasmid-borne copies of nodD2 enhanced protein binding to the nodD1-associated region and rendered the process flavonoid independent. DNase I footprinting analysis and gel retardation experiments with an oligonucleotide DNA probe localized the protein-binding site to a nod box-like sequence that lies just upstream from the nodD1 coding region. Antibodies raised against a NodD2 fusion protein and capable of reacting both with NodD1 and NodD2 blocked formation of the retarded protein-DNA complex.
\end{abstract}

Bacteria of the genera Rhizobium, Bradyrhizobium, Mesorhizobium, Sinorhizobium, and Azorhizobium are collectively known as rhizobia. These organisms are of great agronomic and ecological significance, because they enter into symbiosis with legume plants and produce nitrogen-fixing nodules. Nodulation is a complex developmental process that is controlled by the activities of nodulation, or nod, genes of rhizobia (Pueppke 1996). The initial infection event is regulated by nodD, which encodes a protein that functions as host sensor. nodD is known to be transcribed under normal growth conditions, and its protein product binds to the nod box, a specialized cis-acting promoter that precedes and controls the expression of a series of inducible nod genes (Györgypal et al. 1991;

Corresponding author: Hari B. Krishnan

E-mail krishnan@psu.missouri.edu
Schlaman et al. 1992). These genes are not ordinarily expressed, even when NodD is associated with their promoters, but they are rapidly activated when flavonoid signals from a legume host become available. NodD, an LysR-type transcriptional activator (Schell 1993), is thought to physically bind flavonoid molecules and then deform the DNA helix, so that transcription can commence (Fisher and Long 1993).

Rhizobia have evolved a variety of strategies to deploy NodD as a symbiotic regulator (reviewed by Pueppke 1996). Strains of some biovars of Rhizobium leguminosarum have a single $\operatorname{nod} D$ gene, and if it is inactivated, nodules cannot be produced. Other species, most prominently S. meliloti and $R$. tropici, lie at the other extreme. They harbor three or more divergent nodD alleles, each encoding a protein capable of activating transcription under a specialized set of conditions. In $S$. meliloti, for example, nodD1 is flavonoid regulated, nodD2 is responsive to betaines, and nodD3 is part of a special circuit that functions independently of inducer molecules. Although inactivation of all three nodD copies prevents $S$. meliloti from forming nodules, individual or pairwise inactivation leads to reduced nodulation efficiency and restriction of host range (Göttfert et al. 1986; Honma and Ausubel 1987; Györgypal et al. 1988; Honma et al. 1990).

We are interested in $S$. fredii, which nodulates soybean but can also enter into symbiosis with a broad range of additional legume species (Keyser et al. 1982; Krishnan and Pueppke 1994). Like two other soybean symbionts, Bradyrhizobium japonicum (Göttfert et al. 1992) and B. elkanii (Dobert et al. 1994), $S$. fredii has two copies of nodD, which have been designated nodD1 and nodD2. nodD1 and nodD2 of two $S$. fredii strains, USDA191 and USDA257, have been examined, and the DNA sequences of the corresponding genes are identical (Appelbaum et al. 1988; Krishnan et al. 1995). The proteins encoded by nodD1 and nodD2, though, have primary amino acid sequences that are only $69 \%$ identical to one another. Although the relative roles of nodD1 and nodD2 in activating expression of inducible nod genes in $S$. fredii are unknown, there is evidence that they play very different roles in nodulation (Appelbaum et al. 1988). A nodDl-negative mutant of strain USDA191 produced about one-third fewer nodules on soybean than did the wild type. They were smaller than normal, and the rate of nitrogen fixation was less than half that in controls. The symbiotic consequences of inacti- 
vating nodD2 were milder-nodulation was delayed, but the ultimate rate of nitrogen fixation was unaffected. Since only nodDl was able to complement a nodD-negative mutant of $R$. leguminosarum bv. trifolii for nodulation of white clover, this gene has been assigned the primary regulatory role in the soybean-S. fredii symbiosis (Appelbaum et al. 1988).

We have examined the relationship between nodD1 and nodD2 of $S$. fredii and demonstrate that these two regulatory genes are expressed differentially. We show that expression of nodD1 is influenced by nodD2 and that a nod box-like region upstream from nodDl can bind cellular proteins. We also present immunological evidence that the binding protein is NodD2 and/or NodD1.

\section{RESULTS}

nodD1 and nodD2 are differentially expressed in S. fredii.

Patterns of expression of nodD1 and nodD2 were examined by RNA dot blots with DNA probes corresponding to the divergent C-terminal portions of the two genes. nodDl was expressed in wild-type strain USDA191; transcript levels were greatly enhanced when extra copies of the gene were provided on plasmid pHBK320, and they were elevated slightly following induction with genistein (Fig. 1A). Unexpectedly, though, extra copies of nodD2 on plasmid pHBK330 decreased expression of nodDl to below the limit of detection. The response of nodD2 was much different. Expression was below the level of detection in the wild-type strain and in USDA191(pHBK320). Extra plasmid-borne copies of nodD2 led to an obvious signal, which was slightly intensified if the cells had been grown in the presence of flavonoid (Fig. 1B). We employed similar blots to monitor transcript levels in the mutant genetic backgrounds (data not shown). nodD1 was not expressed in the double mutant, but transcript levels in the nodD2-negative background remained at about the wild-type level. The nodD2 transcript was detectable in neither the nodD1-negative mutant nor the double mutant.

A
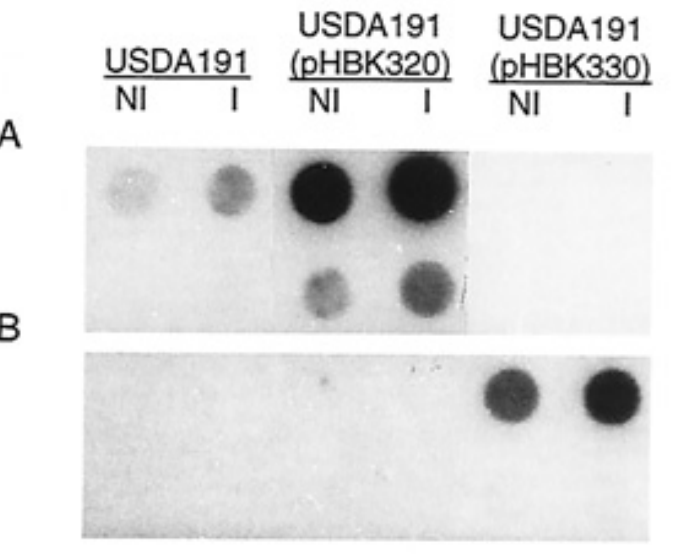

$10 \mu \mathrm{g}$

$1 \mu \mathrm{g}$

$10 \mu \mathrm{g}$

$1 \mu \mathrm{g}$

Fig. 1. RNA dot blot analysis of the expression of nodD1 and nodD2. The nodD1-specific probe (A) and the nodD2-specific probe (B) were hybridized to RNA samples isolated from noninduced (NI) or genisteininduced (I) cells. Amount of RNA blotted onto the nitrocellulose is indicated to the right. A replica of the blots was hybridized to a ribosomal RNA probe to verify that equivalent amounts of RNA had been loaded (data not shown).

\section{DNA sequences upstream of nodD1 are recognized by cellular proteins.}

The observation that expression of nodDl is greater than that of nodD2 and influenced by levels of nodD2 prompted us to search for potential regulators capable of binding to the nodD1 promoter region (Hong et al. 1987; Fisher et al. 1988). Proteins were extracted from cells of USDA191 and the mutant strains and then tested for their capacities to retard the migration of a 441-bp XbaI/BamHI fragment that encompasses the previously tested nodDl promoter region. A low mobility complex was formed in the presence of proteins from strain USDA191 and USDA191(pHBK320), but only if cells had been cultured in the presence of genistein (Fig. 2A). Proteins from both uninduced and genistein-induced cells of USDA191(pHBK330), the strain containing extra copies of nodD2, also produced this complex, but at a substantially greater intensity. Proteins from mutants lacking either or both nodD genes did not yield a retarded band (Fig. 2A). The low mobility complex was absent if reactions contained an excess of unlabeled DNA probe or if protein extracts had been boiled

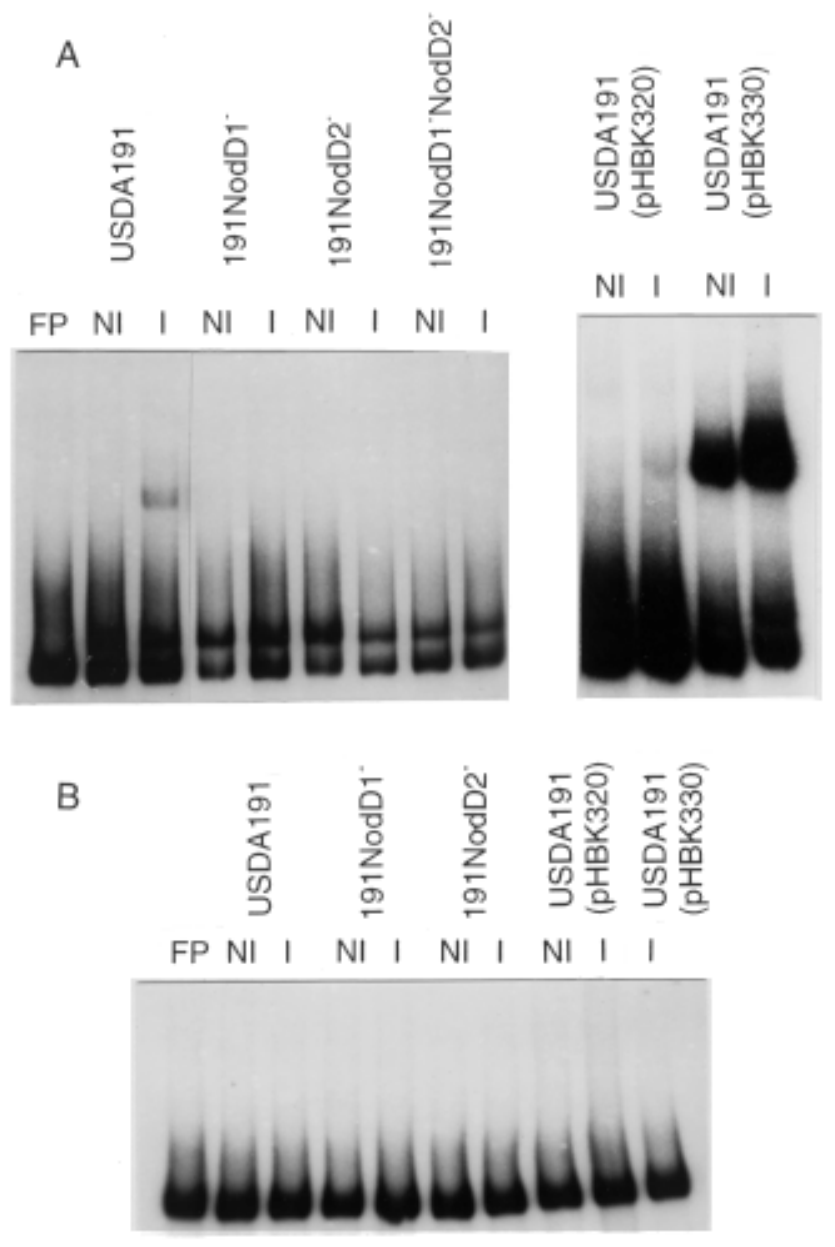

Fig. 2. Analysis of nodD1 and nodD2 promoter regions by gel retardation. Proteins were extracted from genistein-induced (I) or noninduced (NI) bacterial cells and assessed for their abilities to retard electrophoretic migration of two DNA fragments: A, 441-bp BamHI/XbaI fragment containing the 353-bp promoter region of nodD1; B, 429-bp BamHI/ $X b a \mathrm{I}$ fragment containing the $337-\mathrm{bp}$ promoter region of nodD2. $\mathrm{FP}=$ free probe incubated in absence of proteins. 
or treated with Proteinase K (data not shown). Retarded bands also were missing when we used the corresponding probe from the nodD2 promoter region (Fig. 2B).

The nodDl coding region is adjacent to a $\mathrm{PacI}$ site that lies just 15 bp upstream from a nod box-like sequence (Fig. 3) that was first identified by Appelbaum et al. (1988). We used this enzyme to divide the cloned promoter region from pCRIID1 into a proximal 119-bp XbaI/PacI subfragment, which included $72 \mathrm{bp}$ of the promoter region, and a distal 322-bp PacI/ BamHI subfragment, which contained the remaining 279 bp. Proteins from USDA191(pHBK330) retarded migration of the smaller but not the larger fragment (Fig. 4). Since this fragment contains the nod box-like region, we synthesized a pair of 31-mer oligonucleotides and annealed them to create a double-stranded probe that was homologous to the most extensively conserved portion of this sequence (Fig. 5A). Migration of this oligonucleotide fragment was retarded, both by proteins from flavonoid-induced and control cells of USDA191(pHBK330). An excess of unlabeled oligonucleotide prevented the appearance of the retarded complex (Fig. 4 ), and thus this reaction is sequence specific.

We localized the protein binding site by DNase I footprint analysis with end-labeled DNA strands. Although protein extracts from USDA191(pHBK330) failed to protect the template strand, about 50 bases of the nontemplate strand were protected (Fig. 6). This sequence spans a block of nucleotides from position -66 to position -118 with respect to the initiation codon of nodD1 and includes one gap of about 10 unprotected bases. The protected region thus encompasses the nod box-like sequence and extends about 12 bp upstream from it (Fig. 6).

Anti-NodD2 antibodies prevent the formation of a protein complex with the nod box-like sequence preceding nodD1.

Using the vector PGEX-2T, we expressed fusion proteins from nodD1 and nodD2 in both the correct and the reverse orientation with respect to glutathione-S-transferase (GST). The 26-kDa GST protein was present in extracts of $E$. coli cells containing the vector alone or the vector with either insert in the reverse orientation (Fig. 7A, lanes 2, 4, and 6). Extracts of cells containing the plasmid with nodD1 or nodD2 in the proper orientation produced a protein band of about 61 $\mathrm{kDa}$, the expected size of the NodD1-GST and NodD2-GST fusion proteins (lanes 3 and 5).

Figure $7 \mathrm{~B}$ is a Western blot (immunoblot) that was probed with anti-NodD2 antibodies. As expected, a protein band of about $61 \mathrm{kDa}$ was detected in extracts of $E$. coli producing the NodD2-GST fusion (Fig. 7B, lane 7). A faint protein band of about $35 \mathrm{kDa}$, the size expected for NodD1 and NodD2, was present in extracts from strain USDA191(pHBK330), whether or not genistein had been present in cultures (lanes 5 and 6). The corresponding band was absent in extracts of wild-type USDA191 and nodD-negative mutants derived from it (lanes 1-4). All $S$. fredii extracts contained cross-reactive protein bands of about 40 and $60 \mathrm{kDa}$, and E. coli produced a crossreactive band of less than $30 \mathrm{kDa}$. The sizes of these proteins and their presence in nodD-negative mutants incapable of producing proteins that retard the migration of sequences associated with nodD1 (Fig. 1) indicate that they cannot represent NodD. A similar, 59-kDa protein is known to bind to immobilized anti-NodD antibodies from S. meliloti (Fisher et al. 1988), but it did not interfere with gel retardation assays. Western blots with anti-NodD1 antibodies gave similar results (data not shown).

We employed anti-NodD2 antibodies in gel retardation assays to test the hypothesis that NodD1 and/or NodD2 bind to the nod box oligonucleotide. As expected, neither the antiNodD2 antibodies nor preimmune serum complexed directly with the labeled probe in the absence of cellular proteins (Fig. 8 , lanes 1 and 2). Cellular proteins led to the appearance of the anticipated band, but it was absent if extracts had been allowed to react with the antibodies prior to assay (compare lanes 3 and 4). Pretreatment with preimmune serum did not remove the retarded band, indicating that the blocking reaction is specific (Fig. 8, lane 5).
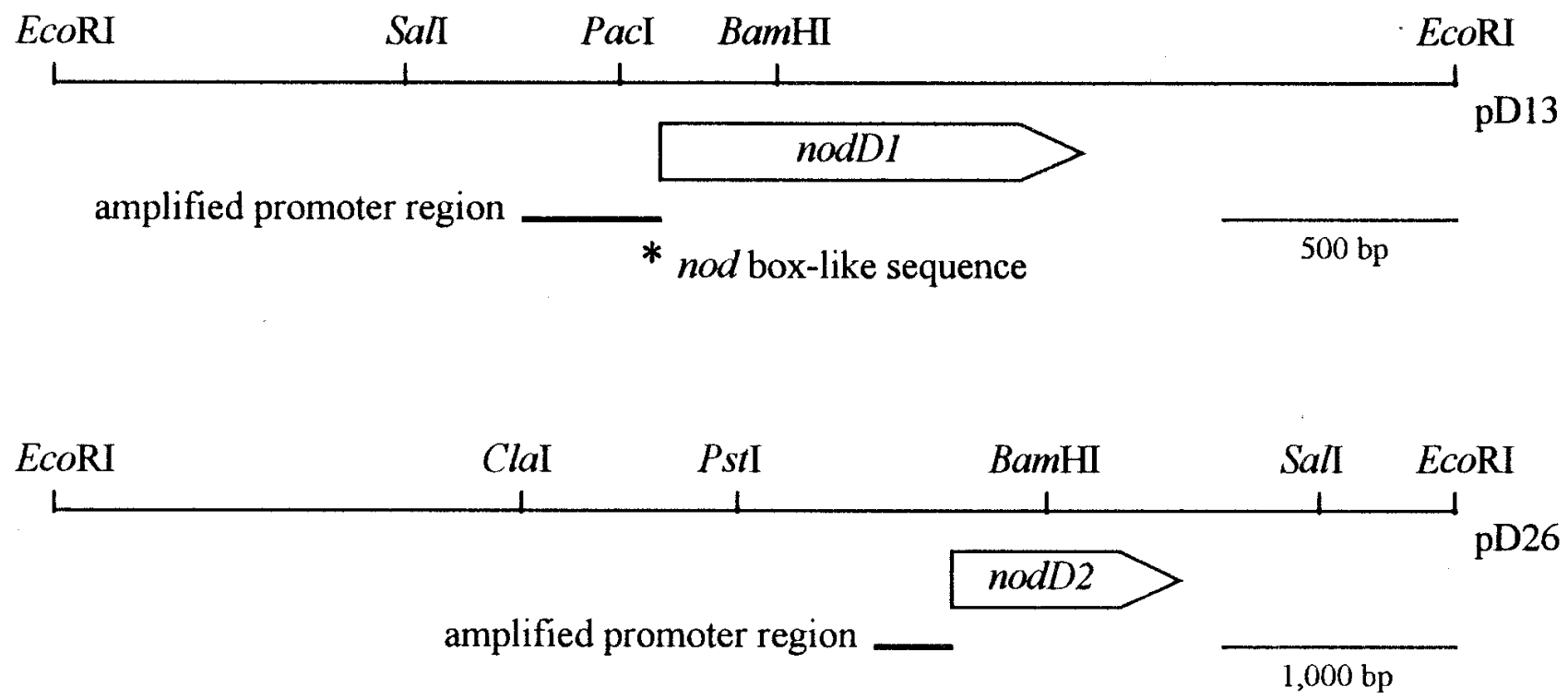

Fig. 3. Restriction maps of EcoRI fragments containing nodD1 and nodD2 of Sinorhizobium fredii. Open reading frames were established by sequencing. Heavy lines identify polymerase chain reaction-amplified promoter regions of the two genes; asterisk marks position of the nod box-like sequence that precedes nodD1. 


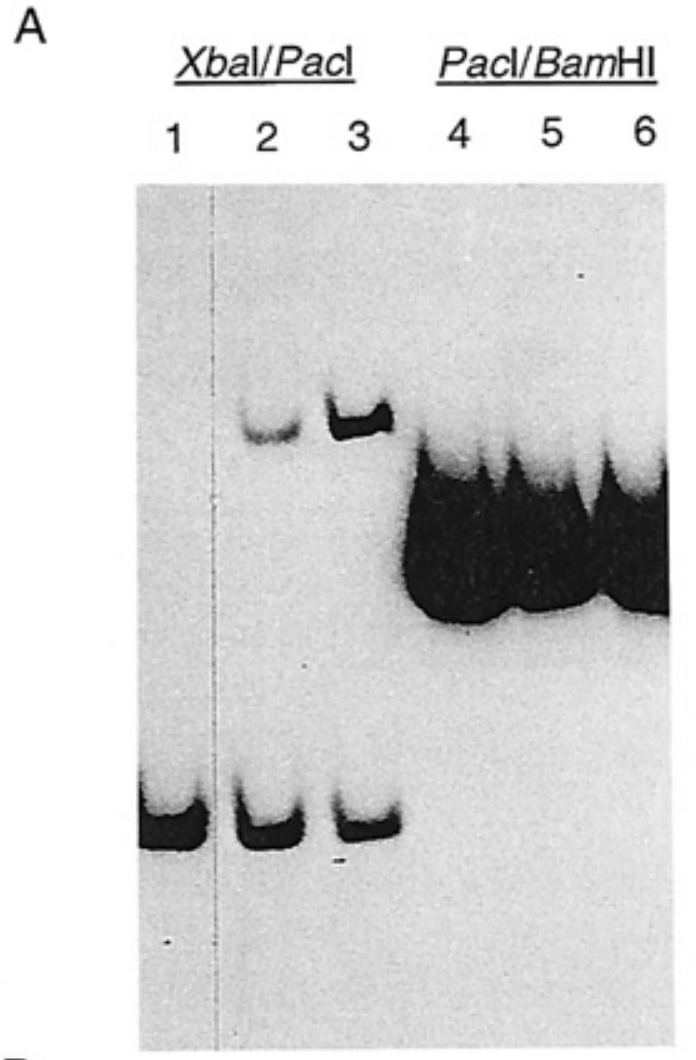

B

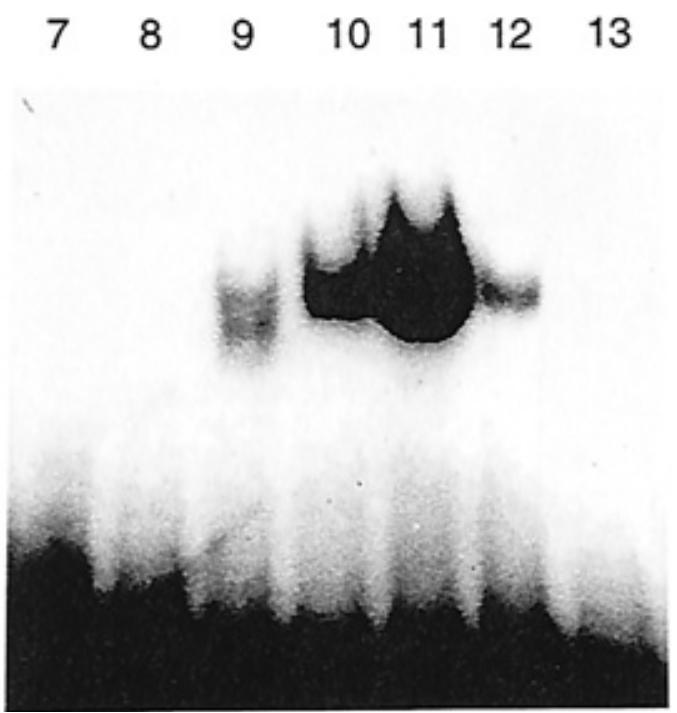

Fig. 4. Localization of protein-binding sequences upstream of nodD1. Unless otherwise noted, $25 \mu \mathrm{g}$ of proteins from genistein-induced cells was assayed as described in Materials and Methods. A, Restriction fragments as probes. B, Synthetic nod box oligomer as probe. Lanes 1, 4 , and $7=$ free probe incubated in absence of proteins. Protein sources as follows: lanes 2, 5, and $11=$ USDA191(pHBK330); lanes 3 and $6=$ USDA191(pHBK330), $50 \mu \mathrm{g}$ of protein; lane $8=$ noninduced USDA191; lane $9=$ USDA191; Lane $10=$ noninduced USDA191 $($ pHBK330); lane $11=$ USDA191 $($ pHBK330); lanes 12 and $13=$ USDA191(pHBK330) incubated with 0.02 and $0.2 \mathrm{ng}$, respectively, of unlabeled oligomer.

\section{DISCUSSION}

nodD governs expression of the inducible nod genes in rhizobia, and so it occupies a pivotal position in the genetic hierarchy that controls the initiation and development of nitrogen-fixing symbioses (Schlaman et al. 1992). This gene encodes a cis-acting transcriptional activator that binds to conserved nod box promoters and then triggers expression of the associated genes, but only under the appropriate conditions. In most cases, flavonoid signals from the host are required for nodD-dependent gene activation, and this recognition process leads to the synthesis of lipooligosaccharides that function as return signals to stimulate nodule development (Dénarié et al. 1996).

Rhizobia synthesize NodD under normal conditions in culture (Schlaman et al. 1992). Expression of nodD can nevertheless be influenced by transcriptional activators and repressors (Kondorosi et al. 1989, 1991; Cren et al. 1995; Garcia et al. 1996), and it is known to be modulated by its own protein product, sometimes positively (Banfalvi et al. 1988; Davis and Johnson 1990b; Wang and Stacey 1991) and sometimes negatively (Rossen et al. 1985; Spaink et al. 1987). The soybean symbiont, Bradyrhizobium japonicum, for example, harbors two copies of nodD (reviewed by Stacey et al. 1995). nodD1 is expressed to a considerably lesser degree than nodD2 (Garcia et al. 1996), but $\beta$-galactosidase activity of a nodD1lac $Z$ gene fusion is enhanced by both flavonoid treatment and NodD1 protein (Banfalvi et al. 1988; Smit et al. 1992). NolA appears to act as a positive regulator in this system, specifically of nodD2 (Garcia et al. 1996).

We show here that differential expression of nodDl and nodD2 characterizes another soybean symbiosis, that with $S$. fredii. In contrast to B. japonicum, the basal level of nodD1 expression in $S$. fredii is much greater than that of nodD2, and analysis of RNA from wild-type cells and cells containing plasmid-borne gene copies confirms that transcript levels of both genes are elevated slightly by genistein. Unexpectedly, extra plasmid-borne copies of nodD2 reduced the level of nodD1 transcripts in $S$. fredii to below the limits of detection. There is evidence that nodD2 can function as a repressor of nod genes in bradyrhizobia. The flavonoid-inducibility of nod $C$ of $B$. japonicum, for example, is virtually abolished by elevated levels of NodD2 (Garcia et al. 1996). Similarly, expression of nolA in a Bradyrhizobium strain from peanut is enhanced in a nodD2-negative background (Gillette and Elkan 1996). There is no evidence, though, that repression by NodD2 is mediated by nodD1 in these systems.

We employed gel mobility shift assays (Carey 1991) to show that cellular proteins bind to DNA sequences upstream of nodDl, in a manner analogous to the binding of NodD to the nod box (Hong et al. 1987; Fisher et al. 1988). Using a combination of methods, we have made three key observations about the retarded complex: (i) the binding target corresponds to a nod box-like sequence that precedes nodD1; (ii) elevation of the copy number of nodD2 renders the binding process flavonoid-independent; and (iii) antibodies capable of recognizing NodD can block formation of the retarded complex. These observations are consistent with the hypothesis that NodD2 and/or NodD1 bind to the nod box-like sequence and consequently reduce expression of nodDl. The nod boxlike sequence has substantial homology (Fig. 5B) to the con- 
sensus nod box as defined by Spaink et al. (1987). Twenty-six of 32 nucleotides are conserved, as opposed to 28 of 32 for the $S$. fredii nodABC-associated nod box (Krishnan and Pueppke 1991) and only 13 of 32 for the B. japonicum nodD1associated nod box (Wang and Stacey 1991). The T-N $\mathrm{N}_{11}$-A repeat motifs that are believed to be significant for NodD binding (Schell 1993) also are present, and so it is not surprising that NodD is able to associate with this sequence.

nod box-like elements regulate expression of nodD in at least two rhizobia. One such sequence is poorly conserved and positioned $84 \mathrm{bp}$ upstream of nodD1 of B. japonicum (Banfalvi et al. 1988; Wang and Stacey 1991). In R. leguminosarum bv. phaseoli, a similar element lies about 700 bp upstream of nodDl and is separated from it by another nod gene, nolE (Davis and Johnston 1990a, 1990b). Removal of these sequences blocks flavonoid-inducibility of nodDl in $B$. japonicum and abolishes nodDl transcription in $R$. leguminosarum bv. phaseoli, indicating that both elements have positive functions.

The nodD1-associated nod box of $S$. fredii is much more similar to the consensus sequence than are the elements of $B$. japonicum and R. leguminosarum bv. phaseoli (Spaink et al. 1987), but it precedes nodDl by just $10 \mathrm{bp}$ and lies on the noncoding strand, oriented away from the gene. This structural relationship raises the possibility that the sequence may be part of a complex promoter region that regulates the expression of a divergently positioned nod gene. We have sought this gene by sequencing about 1,100 bp of DNA beyond the nod box-like element (data not shown). This $S$. fredii sequence is highly homologous to the corresponding region from Sinorhizobium sp. NGR234 (Freiberg et al. 1997); neither, however, harbors appropriately oriented reading frames in the vicinity of the nod boxlike element. In the future, we hope to mutate the nod boxlike element and measure the effect both on protein binding and expression of nodD1. We also plan to assess the significance of relative levels of NodD1 and NodD2 on symbiosis with soybean and other hosts of $S$. fredii.

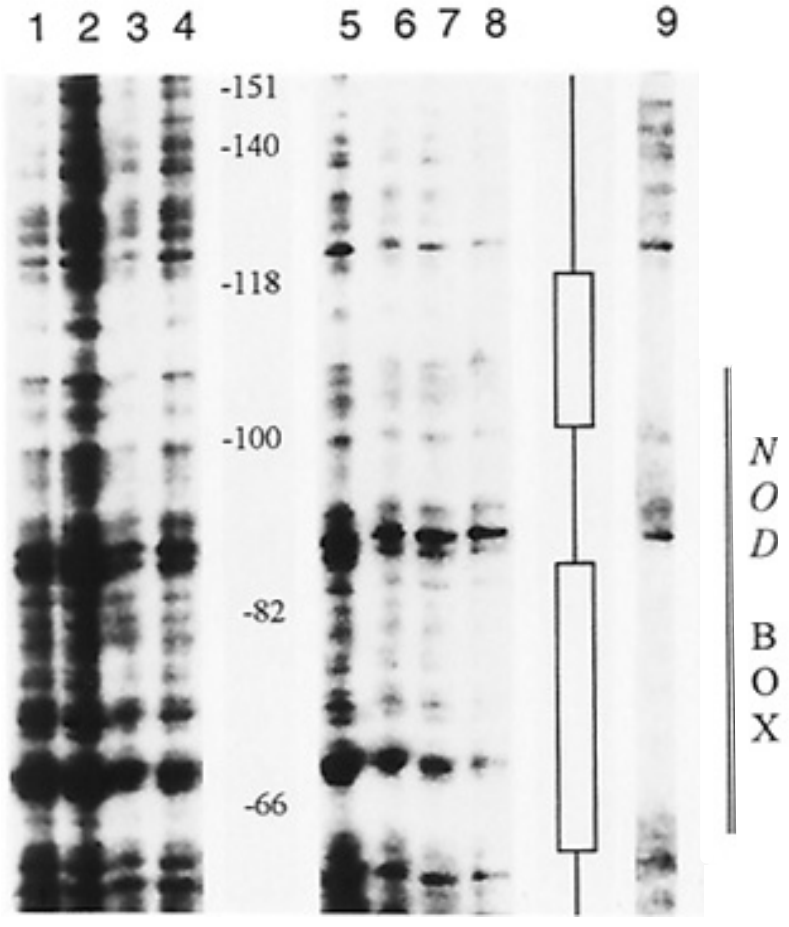

Fig. 6. DNase I footprinting analysis of the nodD1 promoter region. A Bam HI/XbaI fragment was end-labeled as described in Materials and Methods and then digested with XhoI or SpeI to create labeled nontemplate strand (lanes 1-4) or template strand (lanes 5-9) with respect to the orientation of nodD1. Lanes 1 and 5 contain sequencing ladders. DNA in lanes 2 and 6 was treated with $85 \mu \mathrm{g}$ of protein, that in lanes 3 and 7 with $95 \mu \mathrm{g}$ of protein, and that in lanes 4 and 8 with $105 \mu \mathrm{g}$ of protein. DNA in lane 9 was treated with $250 \mu \mathrm{g}$ of protein. Location of sequences with respect to translational start site of nodD1 is given between lanes 4 and 5. Positions of protected regions are diagrammed as open boxes between lanes 8 and 9; location of nod box-like region is identified with a vertical double line to the far right.

\section{Consensus nod box}

\section{R. fredii nodA \\ R. fredii nodD1 \\ B. japonicum nodD1}

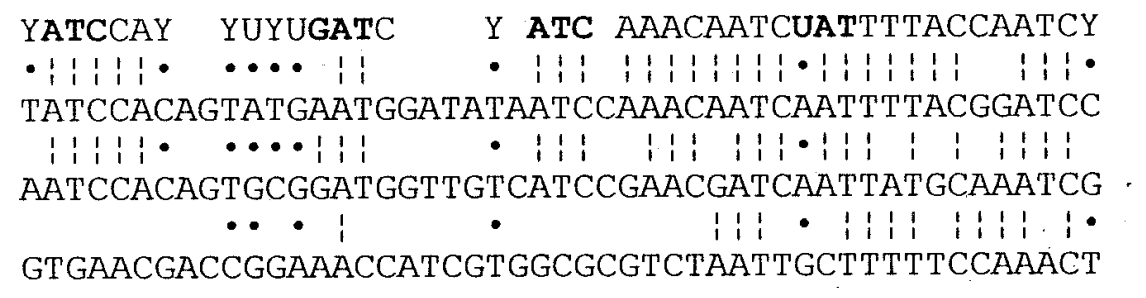

Fig. 5. nodD1-associated nod box-like sequence of strain USDA191. A, Double-stranded synthetic oligonucleotide probe that was used in gel retardation experiments. Bases homologous to those in the consensus nod box are marked with asterisks. B, Alignment of nodD1-associated nod box-like sequence with nodA-associated nod box of Rhizobium fredii (Krishnan and Pueppke 1991), nodDl-associated nod box of Bradyrhizobium japonicum (Banfalvi et al. 1988), and consensus nod box (Spaink et al. 1987). Identical bases are marked with (!) and conserved purines or pyrimidines with (•). 


\section{MATERIALS AND METHODS}

\section{Bacterial strains and plasmids.}

Table 1 lists strains and plasmids used in this study. Bacteria were maintained as stock cultures at $-70^{\circ} \mathrm{C}$. Rhizobia were cultured at $28^{\circ} \mathrm{C}$ in yeast extract-mannitol (YEM) medium (Vincent 1970), and Escherichia coli was grown in Luria-

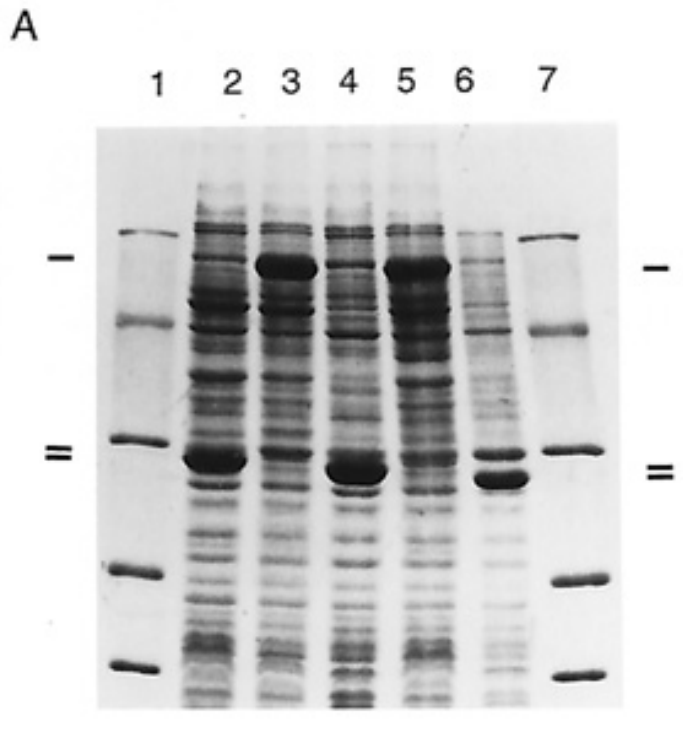

B

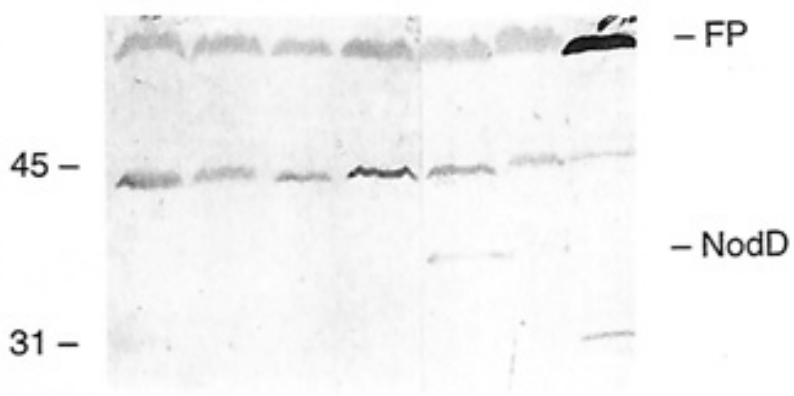

Fig. 7. Expression of NodD1 and NodD2 as glutathione-S-transferase (GST) fusion proteins and immunological detection of NodD in Sinorhizobium fredii. A, Fusion proteins. First $963 \mathrm{bp}$ of nodD1 coding region and first $936 \mathrm{bp}$ of nodD2 coding region were ligated into expression vector pGEX-2T. Cellular proteins were extracted and resolved on sodium dodecyl sulfate-polyacrylamide gels as described in Materials and Methods. Lanes 1 and $7=$ protein size markers of 66, 45, 31, 21, and 14 $\mathrm{kDa}$, from top to bottom; lane $2=\mathrm{pGEX}-2 \mathrm{~T}$ vector alone; lane $3=\mathrm{in}-$ frame $\operatorname{nodD1}$-fusion; lane $4=\operatorname{nodD} 1$ in reverse orientation; lane $5=$ inframe nodD2-fusion; lane $6=$ nodD2 in reverse orientation. Fusion protein band (present in lanes 3 and 5) and GST protein band (present in lanes 2, 4, and 6) are bracketed between single and double bars, respectively. B, Immunological detection of NodD. Cellular proteins were isolated and electrophoresed as described in Materials and Methods. Anti-NodD2 antibodies were used as the immunological probe. Lane $1=$ noninduced strain USDA191; lane $2=$ genistein-induced strain USDA191; lane $3=$ noninduced strain 191 nodD $^{-}$; lane $4=$ noninduced strain 191nodD2 $2^{-}$; lane $5=$ noninduced strain USDA191(pHBK330); lane 6 = induced strain USDA191(pHBK330); lane 7 = Escherichia coli DH5 $\alpha$ carring pGEX-2T with the in-frame nodD2-fusion. Cells were induced with $1 \mu \mathrm{M}$ genistein. FP refers to the fusion protein band in lane 7; NodD refers to the NodD protein band in lanes 5 and 6. Positions of molecular size markers (in $\mathrm{kDa}$ ) are given to the left.
Bertani (LB) medium at $37^{\circ} \mathrm{C}$ (Sambrook et al. 1989). Antibiotics were added at the following concentrations $(\mu \mathrm{g} / \mathrm{ml})$ : carbenicillin (100), kanamycin (50), spectinomycin (25), tetracycline (10).

\section{Responsiveness of nodD1 and nodD2 to flavonoid signals.}

Expression of nodD1 and nodD2 was assessed with RNA dot blots, essentially as described by Balatti et al. (1995). RNA was extracted from early log-phase cultures that had been grown in the presence or absence of $1 \mu \mathrm{M}$ genistein as inducer (Wang and Stacey 1991) and blotted to nitrocellulose (Sambrook et al. 1989). Amounts were verified by probing with radioisotope-labeled DNA that was homologous to rRNA sequences (Scott-Craig et al. 1991). The nodD1 probe was a 1.4-kb BamHI/EcoRI fragment that contains $698 \mathrm{bp}$ of the Cterminal coding region of the gene and the nodD2 probe was an analogous 1.8-kb Bam HI/EcoRI fragment that contains 527 bp of the C-terminal coding region of the gene.

\section{Protein-DNA interaction.}

Primers 5'-CCGACAGATCAGCTTTGC-3' and 5'-GTTC TGGCGAATCCACAG-3' were used in a standard polymerase chain reaction (PCR) protocol (Young et al. 1991) to amplify 353 bp of DNA from plasmid pD13. This sequence begins precisely at the translational start codon of nodD1 and extends upstream from the gene. The primers 5'-GAAGAAC AGGCTAACCAA-3' and 5'-TATTTAATTCAACCAAAG-3' were used to amplify an analogous 337-bp strand of DNA from plasmid $\mathrm{pD} 26$, which included sequences immediately upstream of nodD2. Note that both pD13 and pD26 were originally derived from $S$. fredii strain USDA257 and that we have sequenced the relevant upstream regions (Krishnan et al. 1995) to verify that they are identical to the corresponding regions from strain USDA191 (Appelbaum et al. 1988). The PCR-amplified promoter regions of nodD1 and nodD2 were cloned into plasmid pCRII to create pCRIID1 and pCRIID2, respectively (Table 1), and the intactness of the two sequences verified by automated sequencing.

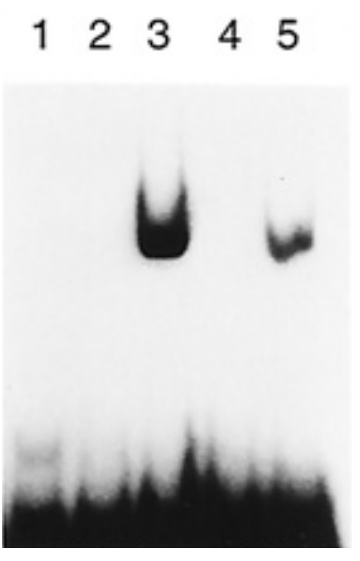

Fig. 8. Anti-NodD2 antibodies prevent formation of the protein-DNA complex. Proteins were extracted from genistein-induced cells of strain USDA191(pHBK330) and incubated with a synthetic nod box oligonucleotide probe prior to assay. Treatments as follows: lane $1=$ antiNodD2 antibodies alone with no cellular proteins; lane $2=$ preimmune serum alone with no cellular proteins; lane $3=$ cellular proteins with no antibodies; lane $4=$ cellular proteins treated with anti-NodD2 antibodies; and lane $5=$ cellular proteins treated with preimmune serum. 
The probe for the nodDl promoter region was a 441-bp XbaI/BamHI fragment from pCRIID1 that contains $349 \mathrm{bp}$ of upstream nontranslated sequences, and the probe for nodD2 was an analogous 429-bp XbaI/BamHI fragment from pCRIID2 that contains 337 bp of upstream nontranslated sequences. Both fragments drove transcription of lac $Z$ when subcloned in the appropriate orientations into promoter probe pMP220 (Spaink et al. 1987) and transferred into USDA191 (data not shown). In some experiments, the 441-bp XbaI/ BamHI fragment was subdivided into 119-bp XbaI/PacI and 322-bp PacI/BamHI fragments. In others, we used a doublestranded, 27-mer oligonucleotide that corresponds to the conserved part of a nod box-like sequence that precedes nodD1. Two complementary oligonucleotides were synthesized (Fig. $5 \mathrm{~A}$ ), and $10 \mu \mathrm{l}$ of each 31-mer was annealed as described by Fisher et al. (1988) prior to use as probe.

The binding of cellular proteins to DNA fragments was measured by gel retardation assays, essentially as described by Kondorosi et al. (1989). Cells were cultured in the presence or absence of $1 \mu \mathrm{M}$ genistein as inducer for $24 \mathrm{~h}$ prior to isolation of proteins (Bellato et al. 1996). Reactions generally contained 2 $\mu \mathrm{l}$ of $20 \times$ binding buffer (Kondorosi et al. 1989), $1 \mu$ of herring sperm DNA $(1 \mathrm{mg} / \mathrm{ml}), 25 \mu \mathrm{g}$ of protein from $S$. fredii cells, and $5 \mu$ of radioisotope-labeled DNA probe in a total volume of 20 $\mu \mathrm{l}$. After $30 \mathrm{~min}$ at $23^{\circ} \mathrm{C}$, reactions were stopped by the addition of $30 \%$ glycerol containing $0.25 \%$ bromophenol blue and $0.25 \%$ xylene cyanol. Nucleoprotein complexes were separated from unbound probe by polyacrylamide gel electrophoresis in 5\% gels and detected by autoradiography.

\section{Preparation and use of antibodies.}

Fusions between GST and nodD1 or nodD2 were constructed with the GST Gene Fusion System of Pharmacia LKB (Kovács et al. 1995). The primers 5'-ATGCGTTTT AAGGGCCTTGAT-3' and 5'-CTCAAGGGTGGCGAGTTG CGC-3' were used to amplify the coding region of nodD1, and the primers 5'-ATGCGTTTTAAGGGCCTTGAT-3' and 5'AAAGCCGGTCAAAT-3' were used to amplify the coding region of nodD2, both by PCR as described above. The amplified fragments were cloned into pCRII, excised with EcoRI, and cloned into protein expression vector pGEX-2T as 963and 936-bp inserts, respectively. Orientations were verified by restriction analysis, and predicted fusion proteins of 62 and 61 $\mathrm{kDa}$, respectively, were expressed (Fig. 7). We purified the two fusion proteins by preparative sodium dodecyl sulfate
(SDS)-polyacrylamide gel electrophoresis as described (Krishnan and Okita 1986). Protein in Freund's complete adjuvant was injected into New Zealand white rabbits at $300 \mu \mathrm{g}$ per animal. Injections were boosted twice at 4-week intervals with protein in incomplete adjuvant. Blood was collected 2 weeks after the final injection. Serum antibodies were preabsorbed with protein extracts from E. coli DH5 $\alpha$ (pGEX-2T) and $S$. fredii 191NodD1- NodD2- to minimize nonspecific binding (Harlow and Lane 1988). Antibody preparations (1.2 $\mu \mathrm{l})$ were reacted with $25 \mu \mathrm{g}$ of proteins for $1 \mathrm{~h}$ on ice prior to assay of the proteins by gel retardation as described above.

\section{DNA footprinting.}

The nodDl promoter region (Fig. 2) was excised from pCRIID1 as a BamHI/XbaI fragment, dephosphorylated with shrimp alkaline phosphatase, and labeled with $\left[1 \gamma^{32} \mathrm{P}\right] \mathrm{ATP}$ and polynucleotide kinase (Sambrook et al. 1989). The labeled fragment was digested with either XhoI or SpeI, and individual end-labeled fragments purified from low melt agarose.

The general footprinting protocol has been described (Hochschild 1991). Each of our reaction mixtures contained $25 \mu \mathrm{l}$ of buffer (10 mM Tris-HCl, $\mathrm{pH} 7.5,0.1 \mathrm{M} \mathrm{CaCl}, 3 \mathrm{mM}$ $\mathrm{MgCl}_{2}, 1 \mathrm{mM}$ dithiothreitol [DTT], $0.5 \mathrm{mM}$ EDTA, 5\% glycerol), $16.5 \mu \mathrm{l}$ of sterile, distilled water, $1 \mu \mathrm{l}$ of herring sperm DNA $(1 \mathrm{mg} / \mathrm{ml}), 2.5 \mu \mathrm{l}$ of protein extract, and $5 \mu \mathrm{l}$ of labeled DNA probe $(20,000 \mathrm{cpm})$. After incubation at $23^{\circ} \mathrm{C}$ for 30 min, $50 \mu \mathrm{l}$ of an aqueous solution containing $5 \mathrm{mM} \mathrm{CaCl}_{2}$ and $10 \mathrm{mM} \mathrm{MgCl}$ was added, and after $60 \mathrm{~s}$ at room temperature, $12 \mu \mathrm{l}$ of RQ1 RNase-free DNase also was added. The reaction was terminated after an additional $60 \mathrm{~s}$ at room temperature by adding $90 \mu \mathrm{l}$ of a solution containing $200 \mathrm{mM} \mathrm{CaCl}, 30 \mathrm{mM}$ EDTA, $1 \%$ SDS, and $100 \mu \mathrm{g}$ of yeast RNA per ml. The mixture was extracted with phenol:chloroform:isoamyl alcohol and DNA precipitated by ethanol (Sambrook et al. 1989). Pellets were washed with ethanol and dissolved in $0.1 \mathrm{M}$ $\mathrm{NaOH}$ :formamide $(1: 2, \mathrm{vol} / \mathrm{vol})$ containing $0.1 \%$ each of bromophenol blue and xylene cyanol. Mixtures were heated at $95^{\circ} \mathrm{C}$ for $2 \mathrm{~min}$, centrifuged briefly, and chilled prior to electrophoresis on $6 \%$ polyacrylamide gels.

\section{ACKNOWLEDGMENTS}

This work was supported by competitive research grants from the U.S. Department of Agriculture/National Research Initiative and by the Food for the 21st Century Program of the University of Missouri. It is

Table 1. Strains and plasmids used in this study

\begin{tabular}{|c|c|c|}
\hline Strain/plasmid & Characteristics & Reference \\
\hline \multicolumn{3}{|l|}{ Rhizobium fredii } \\
\hline USDA191 & Wild-type Fix ${ }^{+}$on McCall and Peking soybean & Keyser et al. 1982 \\
\hline 191NodD1 & USDA191 containing a Km${ }^{\mathrm{r}}$ cassette in nodD1 & Appelbaum et al. 1988 \\
\hline 191NodD2 & USDA191 containing a Km${ }^{\mathrm{r}}$ cassette in $n o d D 2$ & Appelbaum et al. 1988 \\
\hline 191NodD1-NodD2 & USDA191 containing an $\Omega$ insertion nodD1 and a $\mathrm{Km}^{\mathrm{r}}$ cassette in nodD2 & Boundy-Mills et al. 1994 \\
\hline Escherichia coli $\mathrm{DH} 5 \alpha$ & Plasmid host & Promega Biotech, Piscataway, NJ \\
\hline pD13 & 3.0-kb EcoRI fragment containing nodD1 in pTZ19u; $\mathrm{Ap}^{\mathrm{r}}$ & Krishnan et al. 1995 \\
\hline pD26 & 6.0-kb EcoRI fragment containing nodD2 in pTZ19u; $\mathrm{Ap}^{\mathrm{r}}$ & Krishnan et al. 1995 \\
\hline pHBK320 & 3.0-kb insert from $\mathrm{pD} 13$ in $\mathrm{pRK} 415, \mathrm{Tc}^{\mathrm{r}}$ & Krishnan et al. 1995 \\
\hline pHBK330 & 6.0-kb insert from pD26 in pRK415, $\mathrm{Tc}^{\mathrm{r}}$ & Krishnan et al. 1995 \\
\hline pCRII & Cloning vector, $\mathrm{Km}^{\mathrm{r}}, \mathrm{Cb}^{\mathrm{r}}$ & Invitrogen, San Diego, CA \\
\hline pCRIID1 & pCRII containing the poly merase chain reaction-amplified promoter region of nodD1 & This study \\
\hline pCRIID2 & pCRII containing the poly merase chain reaction-amplified promoter region of nodD2 & This study \\
\hline pGEX-2T & Glutathione-S-transferase expression vector, $\mathrm{Cb}^{\mathrm{r}}$ & Pharmacia Biotech, Piscataway, NJ \\
\hline
\end{tabular}


Journal Series No. 12,718 of the Missouri Agricultural Experiment Station. We thank Dietrich Werner of Philipps University, Marburg, Germany, for providing facilities for preparation of the manuscript.

\section{LITERATURE CITED}

Appelbaum, E. R., Thompson, D. V., Idler, K., and Chartrain, N. 1988. Rhizobium japonicum USDA 191 has two nodD genes that differ in primary structure and function. J. Bacteriol. 170:12-20.

Balatti, P. A., Kovács, L. G., Krishnan, H. B., and Pueppke, S. G. 1995. Rhizobium sp. NGR234 contains a functional copy of the soybean cultivar specificity locus, nolXWBTUV. Mol. Plant-Microbe Interact. 8:693-699.

Banfalvi, Z., Nieuwkoop, A., Schell, M., Besl, L., and Stacey, G. 1988. Regulation of nod gene expression in Bradyrhizobium japonicum. Mol. Gen. Genet. 214:420-424.

Bellato, C. M., Balatti, P. A., Pueppke, S. G., and Krishnan, H. B. 1996. Proteins from cells of Rhizobium fredii bind to DNA sequences preceding $n o l X$, a flavonoid-inducible nod gene that is not associated with a nod box. Mol. Plant-Microbe Interact. 9:457-463.

Boundy-Mills, K. L., Kosslak, R. M., Tully, R. E., Pueppke, S. G., Lohrke, S., and Sadowsky, M. J. 1994. Induction of the Rhizobium fredii nod box-independent nodulation gene nod $\mathrm{J}$ requires a functional nodD1 gene. Mol. Plant-Microbe Interact. 7:305-308.

Carey, J. 1991. Gel retardation. Methods Enzymol. 208:103-117.

Cren, M., Kondorosi, A., and Kondorosi, E. 1995. NolR controls expression of the Rhizobium meliloti nodulation genes involved in the core Nod factor synthesis. Mol. Microbiol. 15:733-747.

Davis, E. O., and Johnston, A. W. B. 1990a. Analysis of three nodD genes in Rhizobium leguminosarum biovar phaseoli; nodD1 is preceded by nolE, a gene whose product is secreted from the cytoplasm. Mol. Microbiol. 4:921-932.

Davis, E. O., and Johnston, A. W. B. 1990b. Regulatory functions of the three nodD genes of Rhizobium leguminosarum biovar phaseoli. Mol. Microbiol. 4:933-941.

Dénarié, J., Debellé, F., and Promé, J.-C. 1996. Rhizobium lipochitooligosaccharide nodulation factors: Signaling molecules mediating recognition and morphogenesis. Annu. Rev. Biochem. 65:503-535.

Dobert, R. C., Breil, B. T., and Triplett, E. W. 1994. DNA sequence of the common nodulation genes of Bradyrhizobium elkanii and their phylogenetic relationship to those of other nodulating bacteria. Mol. Plant-Microbe Interact. 7:564-572.

Fisher, R. F., Egelhoff, T. T., Mulligan, J. T., and Long, S. R. 1988. Specific binding of proteins from Rhizobium meliloti cell-free extracts containing NodD to DNA sequences upstream of inducible nodulation genes. Genes Dev. 2:282-293.

Fisher, R. F., and Long, S. R. 1993. Interactions of NodD at the nod box: NodD binds to two distinct sites on the same face of the helix and induces a bend in the DNA. J. Mol. Biol. 233:336-348.

Freiberg, C., Fellay, R., Bairoch, A., Broughton, W. J., Rosenthal, A., and Perret, X. 1997. Molecular basis of symbiosis between Rhizobium and legumes. Nature 387:394-401.

Garcia, M., Dunlap, J., Loh, J., and Stacey, G. 1996. Phenotypic characterization and regulation of the nolA gene of Bradyrhizobium japonicum. Mol. Plant-Microbe Interact. 9:625-635.

Göttfert, M., Holzhäuser, D., Bäni, D., and Hennecke, H. 1992. Structural and functional analysis of two different nodD genes in Bradyrhizobium japonicum USDA110. Mol. Plant-Microbe Interact. 5:257-265.

Göttfert, M., Horvath, B., Kondorosi, E., Putnoky, P., RodriguezQuinones, F., and Kondorosi, A. 1986. At least two nodD genes are necessary for efficient nodulation of alfalfa by Rhizobium meliloti. J. Mol. Biol. 191:411-420.

Györgypal, Z., Iyer, N., and Kondorosi, A. 1988. Three regulatory nodD alleles of diverged flavonoid-specificity are involved in host-dependent nodulation by Rhizobium meliloti. Mol. Gen. Genet. 212: 85-92.

Györgypal, Z., Kiss, G. B., and Kondorosi, A. 1991. Transduction of plant signal molecules by the Rhizobium NodD proteins. BioEssays 13:575-581.

Harlow, E., and Lane, D. 1988. Antibodies: A Laboratory Manual. Cold Spring Harbor Laboratory, Cold Spring Harbor, NY.

Hochschild, A. 1991. Detecting cooperative protein-DNA interactions and DNA loop formation by footprinting. Methods Enzymol. 208: 343-361.

Hong, G.-F., Burn, J. E., and Johnston, A. W. B. 1987. Evidence that
DNA involved in the expression of nodulation (nod) genes in Rhizobium binds to the product of the regulatory gene nodD. Nucleic Acids Res. 15:9677-9690.

Honma, M. A., Asomaning, M., and Ausubel, F. M. 1990. Rhizobium meliloti nodD genes mediate host-specific activation of nodABC. J. Bacteriol. 172:901-911.

Honma, M. A., and Ausubel, F. M. 1987. Rhizobium meliloti has three functional copies of the nodD symbiotic regulatory gene. Proc. Natl. Acad. Sci. USA 84:8558-8562.

Keyser, H. H., Bohlool, B. B., Hu, T. S., and Weber, D. F. 1982. Fastgrowing rhizobia isolated from root nodules of soybean. Science 215: 1631-1632.

Kondorosi, E., Gyuris, J., Schmidt, J., John, M., Duda, E., Hoffmann, B., Schell, J., and Kondorosi, A. 1989. Positive and negative control of nod gene expression in Rhizobium meliloti is required for optimal nodulation. EMBO J. 8:1331-1340.

Kondorosi, E., Pierre, M., Cren, M., Haumann, U., Buiré, M., Hoffmann, B., Schell, J., and Kondorosi, A. 1991. Identification of NolR, a negative transacting factor controlling the nod regulon in Rhizobium meliloti. J. Mol. Biol. 222:885-896.

Kovács, L. G., Balatti, P. A., Krishnan, H. B., and Pueppke, S. G. 1995 Transcriptional organization and expression of nolXWBTUV, a locus that regulates cultivar-specific nodulation of soybean by Rhizobium fredii USDA257. Mol. Microbiol. 17:923-933.

Krishnan, H. B., Kuo, C.-L., and Pueppke, S. G. 1995. Elaboration of flavonoid-induced proteins by the nitrogen-fixing soybean symbiont Rhizobium fredii is regulated by both nodD1 and nodD2, and is dependent on the cultivar-specificity locus, nolXWBTUV. Microbiology 141:2245-2251.

Krishnan, H. B., and Okita, T. W. 1986. Structural relationships among rice glutelin polypeptides. Plant Physiol. 81:748-753.

Krishnan, H. B., and Pueppke, S. G. 1991. Sequence and analysis of the nodABC region of Rhizobium fredii USDA257, a nitrogen-fixing symbiont of soybean and other legumes. Mol. Plant-Microbe Interact. 4:512-520.

Krishnan, H. B., and Pueppke, S. G. 1994. Host range, RFLP, and antigenic relationships between Rhizobium fredii strains and Rhizobium sp. NGR234. Plant Soil 161:21-29.

Pueppke, S. G. 1996. The genetic and biochemical basis for nodulation of legumes by rhizobia. Crit. Rev. Biotechnol. 16:1-51.

Rossen, L., Shearman, C. A., Johnston, A. W. B., and Downie, J. A. 1985. The nodD gene of Rhizobium leguminosarum is autoregulatory and in the presence of plant exudate induces the $\operatorname{nod} A, B, C$ genes. EMBO J. 4:3369-3373.

Sambrook, J., Fritsch, E. F., and Maniatis, T. A. 1989. Molecular Cloning: A Laboratory Manual. 2nd ed. Cold Spring Harbor Laboratory, Cold Spring Harbor, NY.

Schell, M. A. 1993. Molecular biology of the LysR family of transcriptional regulators. Annu. Rev. Microbiol. 47:597-626.

Schlaman, H. R. M., Okker, R. J. H., and Lugtenberg, B. J. J. 1992 Regulation of nodulation gene expression by NodD in rhizobia. J. Bacteriol. 174:5177-5182.

Scott-Craig, J. S., Guerinot, M. L., and Chelm, B. K. 1991. Isolation of Bradyrhizobium japonicum DNA sequences that are transcribed at high levels in bacteroids. Mol. Gen. Genet. 228:356-360.

Smit, G., Puvanesarajah, V., Carlson, R. W., Barbour, W. M., and Stacey, G. 1992. Bradyrhizobium japonicum nodD1 can be specifically induced by soybean flavonoids that do not induce the nodYABCSUIJ operon. J. Biol. Chem. 267:310-318.

Spaink, H. P., Okker, R. J. H., Wijffelman, C. A., Pees, E., and Lugtenberg, B. J. J. 1987. Promoters in the nodulation region of the Rhizobium leguminosarum sym plasmid pRL1JI. Plant Mol. Biol. 9:27-39.

Stacey, G., Sanjuan, J., Luka, S., Dockendorff, T., and Carlson, R. W. 1995. Signal exchange in the Bradyrhizobium-soybean symbiosis. Soil Biol. Biochem. 27:473-483.

Vincent, J. M. 1970. A Manual for the Practical Study of Root-nodule Bacteria. Blackwell Science, Oxford.

Wang, S.-P., and Stacey, G. 1991. Studies of the Bradyrhizobium japonicum nodD1 promoter: A repeated structure for the nod box. J. Bacteriol. 173:3356-3365.

Young, J. P. W., Downer, H. L., and Eardly, B. D. 1991. Phylogeny of the phototrophic Rhizobium strain Btail by polymerase chain reaction-based sequencing of a $16 \mathrm{~S}$ rRNA gene segment. J. Bacteriol. 173: 2271-2277. 